\title{
INFLUENCE OF ECOLOGICAL PROTECTION ON THE CORPORATE IMAGE OF OIL AND GAS FIRMS IN NIGERIA
}

\author{
Deborah Bolanle MOTILEWA ${ }^{1}$, Ayodotun Stephen IBIDUNNI ${ }^{2}$, Rowland WORLU ${ }^{3}$, \\ Chinonye Love MOSES ${ }^{4}$, James $\mathrm{OBI}^{5}$, Joy DIRISU ${ }^{6}$
}

\author{
Covenant University, Ota, Nigeria \\ E-mails: ${ }^{1}$ bolanle.motilewa@covenantuniversity.edu.ng; \\ 2 ayodotun.ibidunni@covenantuniversity.edu.ng (corresponding author); ${ }^{3}$ rowland.worlu@covenantuniversity.edu.ng; \\ ${ }^{4}$ chinonye.moses@covenantuniversity.edu.ng; ${ }^{5}$ james.obi@covenantuniversity.edu.ng; \\ 6joy.dirisu@covenantuniversity.edu.ng
}

Received 02 June 2018; accepted 01 November 2018

\begin{abstract}
Oil and gas firms in Nigeria are generally perceived to be weak in their environmental and ecological initiatives towards their host communities. Yet there has been a dearth of empirical emphasis from research that shows evidences about the role of ecological protection on the corporate image of oil and gas firms. Therefore, this study focused on examining the influence of a commitment to ecological protection on the corporate image of oil and gas firms in Nigeria. The study adopted the mixed methods approach where quantitative and qualitative methods (survey and interview) were used. For the quantitative research, copies of structured questionnaire were distributed to 350 employees of the selected firms, while 30 respondents from other stakeholder groups were interviewed for the qualitative research. Based on the results of the regression and thematic analyses, findings show that the firms' commitment to ecological protection through their policy to avoid the use of materials from the illegal exploitation of natural resources, commitment to waste minimisation and recycling and pollution leads to increased investors' confidence, strengthened relationship with the government, host community and reduced pressure from third parties. Therefore, it is recommended that oil and gas firms intensify efforts in activities that ensure ecological protection of host communities and thus build stakeholders confidence in the firms' corporate image.
\end{abstract}

Keywords: ecological protection, corporate social responsibility, corporate image, oil and gas firms, Nigeria.

JEL Classification: M1.

\section{Introduction}

The oil and gas sector has been termed a controversial sector for several decades. This is because there has been persistent, widespread engagement in unprincipled business practices that entail adverse social, environmental, and ethical consequences (Du and Vieira 2012, Woolfson and Beck 2005). Previous studies by Ekpenyong and Udofia (2015) and Fadun (2014) have documented the negative social and environmental consequences of the operations of oil and gas firms, such negative effects as global warming, deterioration in air and water quality for host communities, and the resource curse that has afflicted many countries with abundant oil resources.
In response to the challenges posed by the operations in the sector, oil and gas firms are embracing corporate social responsibility as a means to counter negative public sentiments (Akujobi 2009), as there exists a potential for CSR practices to lead to enhanced corporate performance, through its potential to build corporate image, gain employees loyalty, improve operational competency and ultimately increase profitability. Yet, most corporate social responsibility studies such as Akujobi (2009), Idemudia (2014) and Okike (2007) have dominantly focused on the impact of CSR on the society without showcasing the possible influence of CSR practices on the organisation's performance (Idemudia 2014). 
It is believed that firms that are unable to show a commitment to ecological protection leave their stakeholders, especially their host community with a negative perception of the firm's operations. While Adegbite et al. (2012), Adeyanju (2012) and Mullerat and Brennan (2005) have proven a relationship between firms' commitment to ecological protection and society welfare, there is still a gap between ecological protection through transparent operations and provision of eco-efficient solutions and the firm's corporate image. The existence or otherwise of this relationship is very critical in the Nigerian environment which is characterised by lack of environmental laws and regulations, poor understanding of ecological issues, and lack of commitment to protecting and managing the environment (Akujobi 2009). Therefore, it becomes pertinent to ascertain empirically the extent to which a firm's investment in ecological protection can influence its corporate image.

\section{Literature review}

\subsection{Ecological protection}

Ecological protection as a construct of corporate social responsibility, involves a firm's investment in energy conservation, efficiency, waste minimisation, pollution prevention and recycling (Tudor et al. 2008, Du et al. 2011). Umukoro (2009) defines ecological protection as the firm's duty to cover the environmental implications of its operations, products and facilities, eliminate waste and minimise practices that might adversely affect the sustainability of a country's resources. The firm's commitment to ecological protection advocates for the use of clean technology to create less pollution in the firm's production process. It includes changing inputs, equipment, process parameters and working procedures to ensure less waste is produced, whilst ensuring the use of safe materials in production, environmental issues discourse with host communities and pollution prevention (Visser et al. 2010).

In developing countries, which are usually characterised by weak environmental frameworks, the lack of adequate environmental laws and regulations makes it possible for corporate organisations (especially those involved in extractive industries) to carry out operations that have negative effects on the environment, lives and properties of their host communities (Subai 2009, Motilewa and Worlu 2015). However, firms that show commitment to environmental protection by going beyond that which is stipulated by environmental regulations, gain such benefits as enhanced relationships with the local community, suppliers and consumers and highly motivated employees, thereby creating a positive corporate image across the firm's entire stakeholders (Rangan et al. 2012).

\subsection{Corporate image}

Corporate image depicts the perception the firm's stakeholders have about the organisation (Karadeniz 2009, Yeo and Youssef 2010, Żaba-Nieroda 2011). Similarly, Bateman and Snell (2014) associate corporate image with people's judgment of a company's acceptance, appropriateness and desirability, stemming from the company's goals and methods that are consistent with societal values. It is believed that corporate image creates trust and deters competitors from entering and penetrating the market, thereby serving as a source of competitive advantage.

Carroll and Shabana (2010) posit corporate image as a major motivation for firms to adopt CSR initiatives - it is generally believed that stakeholders prefer to be associated with firms that place emphasis on community development and ecological protection.

\subsection{Ecological protection and corporate image}

A firm's commitment to corporate social responsibility through ecological protection entails maintaining or restoring the quality of the environment by preventing the emission of pollutants or reducing the presence of polluting substances in the environment (OECD 2003). Due to the fact that social issues are becoming more popular on the global scale, protection of the ecological system is seen as a major aspect of CSR. This is particularly necessary in the oil and gas sector, which has proven to be a huge concern to the environment in several countries.

In Nigeria, multinational oil corporations such as Shell, Exxon Mobil and Chevron, amongst others, have for several years combatted with environmental protection challenges (Onakoya et al. 2013). On the world level, these same organisations have frequently gone through rigorous measures to ensure the environment in which they operate is protected from pollution. In 1995, Royal Dutch Shell decided to sink the obsolete oil platform 'Brent Spar' in the North Sea. The massive protests against this action from many European civilians, NGOs, other MNE's and governments, was detrimental to Shell's reputation. This example brings to the fore light the influence a commitment to ecological protection has on the firm's image (Isaksson 2012, Jegede et al. 2016).

In developing countries, which are usually characterised by weak environmental frameworks, the lack of adequate environmental laws and regulations make it possible for corporate organisations (especially those involved in extractive industries) to carry out operations that have negative effects on the environment, lives and properties of their host communities (Subai 2009). However, firms that show commitment to environmental protection by going beyond that which is stipulated by environmental regulations, gain such benefits as enhanced relationships with the local community, suppliers and consumers and highly motivated 
employees, thereby creating a positive corporate image across the firm's entire stakeholders (Rangan et al. 2012, Ibidunni et al. 2018).

\section{Methodology}

The study adopted the mixed methods approach where quantitative and qualitative methods (survey and interview) were used in order to enhance greater validity of the research by ensuring that there are no gaps in the information or data collected and to provide more information from the firms' various stakeholder groups, rather than limiting the study to information from one stakeholder group. Quantitative data through the use of questionnaire, were gotten from employees of the organisations, while qualitative data through the use of interviews, were gotten from other stakeholder groups (consisting of stockholders, suppliers, contractors and community members).

\subsection{Sampling}

The study population consists of the stakeholders of the top four oil and gas firms quoted in the Nigerian stock exchange. For the quantitative research, copies of structured questionnaire were distributed to 350 employees of the selected firms. The selection of 350 employees was based on the Yamane (!967) formula, given the total number of employees in all four firms were 1748 .

For the qualitative research, 30 semi-structured interviews were conducted for the other stakeholder groups (stockholders, suppliers, contractors and community members). The selection of 30 respondents was based on the work of Saunders et al. (2009), where it is stipulated that a sample size of twenty (20) to thirty (30) respondents be adopted when using semi-structured interviews, to give the researcher time to carry out in-depth analysis of the responses.

\subsection{Measures}

The research benefitted from the works of extant scholars in the field of ecological projection (and more broadly corporate social responsibility) and corporate image of firms. More specifically the works of Tudor et al. (2008), Visser et al. (2010), Rangan et al. (2012) and Carroll and Shabana (2010) were essential in drafting the quantitative and qualitative research instruments.

\subsection{Reliability and validity of the scale items}

The content validity was used for this study. Content validity is a question as to whether or not the instrument contains all the necessary elements that enables the researcher measure correctly the attributes of interest. To certify content validity, the questionnaire items were generated from established prominent authors in the field such as Tudor et al. (2008), Visser et al. (2010), Rangan et al. (2012) and Carroll and Shabana (2010). More over, other experts on the research area were given access to the draft questionnaire in order to provide feedback on the effectiveness of each question in measuring the constructs. Their comments were noted and effected in the final draft of the research instrument. The reliability test used for this research is the internal consistency method. The coefficient alpha $(\alpha)$ or Cronbach alpha is the most popularly used measure of internal consistency (Pallant 2005). The Cronbach Alpha internal consistency of the items of the questionnaire was analysed using the reliability procedure in SPSS version 22. The Cronbach alpha value $(\alpha)$ for the research instrument was 0.892 , which surpassed the benchmark of 0.7 .

\section{Results and discussion}

Out of the 350 copies of questionnaire distributed, only 336 were retrieved and analysed for this study. Across the four firms, male respondents were 194 (57.7\%), while female were $142(42.3 \%)$. Respondents under 25 years were 20 (5.9\%), 25-35 years were 144 (42.9\%), 36-45 years were 136 (40.5\%) and 46 years and above were $36(10.7 \%) .75$ (22.3\%) respondents were senior managers, $68(20.2 \%)$ were analysts, 108 (32.3\%) respondents were supervisors and 85 (25.3) respondents were in the category of other workers.

\subsection{Quantitative results}

The standard multiple regression analysis was used to identify the influence of ecological protection on corporate image. The result reflects the influence of each item of ecological protection on corporate image.

Table 1 shows the combined influence of the independent variables (safe materials in production, environmental issues discourse, energy and water conservation, recycling and pollution prevention) on corporate image (the dependent variable) of the firms. Based on the result, ecological protection made significant joint influence on corporate image as $\mathrm{R}$ square value $=0.808$ indicating that the total contribution or influence made by all the independent variables was $80.8 \%$. This signifies that ecological protection had significant joint influence on corporate image of oil and gas firms. The result in the Table further establishes that the composite influence of ecological protection did not occur by chance as it gives the F-ratio value of 152.332 which signifies the strength of the four independent variables (under ecological protection) as potent predictors of corporate image of oil and gas firms. More so, the result in Table shows the staff opinion on the roles of ecological protection in promoting corporate image of oil and gas firms and it reveals that having an explicit policy not to use materials from the illegal exploitation of natural resources 
Table 1. Standard multiple regression of ecological protection and corporate image (source: Researchers' Field Survey 2018)

\begin{tabular}{|c|c|c|c|c|c|}
\hline \multicolumn{6}{|c|}{ Coefficients } \\
\hline & \multicolumn{2}{|c|}{ Standardised Coefficients } & \multirow{2}{*}{$\mathrm{df}$} & \multirow{2}{*}{$\mathrm{F}$} & \multirow{2}{*}{ Sig. } \\
\hline & Beta & Std. Error & & & \\
\hline $\begin{array}{l}\text { The firm has explicit policy not to use materials from the illegal } \\
\text { exploitation of natural resources }\end{array}$ & .573 & .050 & 2 & 128.747 & .000 \\
\hline $\begin{array}{l}\text { The firm participates in local or regional committees discuss on } \\
\text { environmental issues }\end{array}$ & .317 & .052 & 1 & 36.533 & .000 \\
\hline $\begin{array}{l}\text { Reduction of environmental impact in terms of energy conserva- } \\
\text { tion is very vital to the firm }\end{array}$ & .215 & .075 & 1 & 8.133 & .005 \\
\hline The firm is committed to waste minimisation and recycling & .283 & .058 & 1 & 24.008 & .000 \\
\hline The firm invests in pollution prevention & .219 & .049 & 4 & 19.804 & .000 \\
\hline $\mathrm{R}$ & \multicolumn{5}{|c|}{0.899} \\
\hline $\mathrm{R}^{2}$ & \multicolumn{5}{|c|}{0.808} \\
\hline Adj. $\mathrm{R}^{2}$ & \multicolumn{5}{|c|}{0.803} \\
\hline F-value & \multicolumn{5}{|c|}{$9,326=152.332$} \\
\hline Sig. & \multicolumn{5}{|c|}{$0.000(\mathrm{p}<0.01)$} \\
\hline \multicolumn{6}{|c|}{$\begin{array}{l}\text { Predictors: (Constant), Ecological Protection: safe materials in production, environmental issues discourse, energy and water con- } \\
\text { servation, recycling and pollution prevention } \\
\text { Dependent variable: Corporate image }\end{array}$} \\
\hline
\end{tabular}

is a major predictor of corporate image which has the highest beta value of (beta $=.573, \mathrm{p}<.005$, Sig. .000) than other variables: participation in environmental issues discourse scaled (beta $=.317, \mathrm{p}<.005$, Sig. .000), commitment to waste minimisation and recycling scaled (beta $=.283, \mathrm{p}<.005$, Sig. .000), investment in pollution prevention scaled (beta $=$ $.219, \mathrm{p}<.005$, Sig. .000), while Energy and water conservation scaled (beta $=.215, \mathrm{p}<.005$, Sig. .002). This means that safe materials in production and legal exploitation of natural resources makes the strongest unique contribution in influencing corporate image.

\subsection{Qualitative analysis}

Theme: Assessment of the firms' efforts towards Ecological Protection

The qualitative findings on the firm's efforts to improve the environment through a commitment to ecological protection revealed that despite the backlog of technology in Nigeria, oil and gas firms have policies in place to protect the environment. Although various external stakeholders believe that more can be done especially in the aspect of sustainable oil exploration and gas flaring, it is generally perceived that the firm's engagement in ecological protection enhances the firm's image and reputation.

They ensure that policy initiatives that are put in place help protect the environment.

Firm 3/Contractor

They're doing a good job to create an eco-friendly environment.

Firm 2/Community member
To the best of my knowledge, the firm is doing a lot in improving the environment but I think more can be done especially in the aspect of sustainable oil exploration

Firm 1/ Contractor

Encouraging, but not forceful enough to break communal restraints.

Firm 1/Community member

They are reducing gas flaring in their operations, but they need to put in more efforts to eradicate oil spillage

Firm 3/Contractor

They have been involved so far in fumigation and evacuating the dungs in the community I reside.

Firm 4/ Community members

\section{Theoretical and managerial contribution}

The multiple regression analysis revealed that commitment to ecological protection has a significant effect on the corporate image of oil and gas firms. The implication of this finding is that oil and gas firms that have explicit policy not to use materials from the illegal exploitation of natural resources, firms that participate in local or regional committees discus on environmental issues and are committed to waste minimisation, recycling and pollution prevention are rewarded by increased investors' confidence, strengthened relationship with the government and host community, increased employee participation and reduced pressures from third parties.

The qualitative findings on the relationship between ecological protection and corporate image revealed that despite the backlog of technology in Nigeria, oil and gas firms have 
policies in place to protect the environment. Although various external stakeholders believe that more can be done especially in the aspect of sustainable oil exploration and gas flaring, it is generally perceived that the firm's engagement in ecological protection enhances the firm's image and reputation. This finding is in line with that of Camilleri (2012), Kurucz et al. (2008) and Isaksson (2012) where it was observed that the firm's commitment to ecological protection through innovative ecological practices has a synergistic improvement on their reputation and standing amongst their stakeholders.

In the developing country's perspective, the result of this study is in consonance with the findings of Muthuri and Gilbert (2011) and Subai (2009), where it was posited that of all corporate social responsibility issues, firms operating in Africa give ecological protection $74.0 \%$ priority because of its ability to enhance their corporate image in the face of increased global anxiety as to the state of the environment, such as the concerns surrounding oil spillage, exposure to radiation and other ecological hazards. In the Nigerian context this finding is inline with the studies by Ejumudo et al. (2012) and Ndu and Agbonifoh (2014) where it was propositioned that stakeholders of oil and gas firms operating in the Niger Delta specifically, are highly gratified when firms carry out CSR practices with the aim of eradicating environmental pollution.

\section{Conclusions and recommendation}

This study has shown that the firms 'commitment to ecological protection through their policy to avoid the use of materials from the illegal exploitation of natural resources, commitment to waste minimisation and recycling and pollution leads to increased investors' confidence, strengthened relationship with the government, host community and reduced pressure from third parties. However, the external stakeholders of oil and gas firms believe that more can be done especially in the aspect of sustainable oil exploration and gas flaring. Therefore, it is recommended that oil and gas firms intensify efforts in activities that ensure ecological protection of host communities and thus build stakeholders confidence in the firms' corporate image.

\section{Acknowledgements}

Authors of this research work express sincere appreciation to the Management of Covenant University for giving full sponsorship to this research work.

\section{References}

Adegbite A, Amiolemen SO, Ologeh IO, Oyefuga IO (2012) Sustainable development policy and corporate social responsibility in business organisations in Nigeria. Journal of sustainable development 5 (6): 83-89. https://doi.org/10.5539/jsd.v5n6p83
Adeyanju OD (2012) An assessment of the impact of corporate social responsibility on Nigerian society: The examples of banking and communication industries. Universal Journal of Marketing and Business Research 1 (1): 017-043 http://universalresearchjournals.org/ujmbr/pdf/2012/May/Olanrewaju.pdf

Akujobi AT (2009) Corporate social responsibility in Nigeria: an evaluation. In: Emiri F and Deinduomo G (Ed) Law and petroleum industry in Nigeria: current challenges. Lagos: Malthouse Press Limited, 211-221.

Bateman TS, Snell SA (2014) Management: leading in a competitive world $\left(11^{\text {th }}\right.$ ed). New York: McGraw-Hill Education.

Camilleri MA (2012) Creating shared value through strategic CSR in tourism (doctoral dissertation) https://www.era.lib. ed.ac.uk/handle/1842/6564

Carroll AB, Shabana KM (2010) The business case for corporate social responsibility: a review of concepts, research and Practice. International Journal of Management Reviews 12 (1): 85-105. https://doi.org/10.1111/j.1468-2370.2009.00275.x

Du S, Vieira ET (2012) Striving for legitimacy through corporate social responsibility: Insights from oil companies. Journal of Business Ethics 110 (4): 413-427. https://doi.org/10.1007/ s10551-012-1490-4

Du S, Bhattacharya CB, Sen S (2011) Corporate social responsibility and competitive advantage: overcoming the trust barrier. Management Science 57 (9): 1528-1545. https://doi. org/10.1287/mnsc.1110.1403

Ejumudo K, Edo ZO, Avweromre L, Sagay J (2011) Environmental issues and corporate social responsibility (CSR) in Nigeria Niger delta region: the need for a pragmatic approach. Journal of Social Science and Public Policy 4: 1-21.

Ekpenyong NS, Udofia US (2015) Oil pollution and its impact on water quality in Ibeno community. Studies in sociology of science 6 (2): 8-12 http://www.cscanada.net/index.php/sss/ article/viewFile/6398/pdf_113

Fadun SO (2014) Corporate social responsibility (CSR) practices and stakeholders expectations: The Nigerian perspectives. Research in Business and Management 1 (2): 13-31 http://www.macrothink.org/journal/index.php/rbm/article/ view/5500/4380

Ibidunni AS, Olokundun MA, Motilewa DB, Atolagbe TM, Osibanjo OA (2018) Group-tacit knowledge and organisational effectiveness: analysis of effects using a mixed method approach. Business: Theory and Practice 19: 135-145. https:// doi.org/10.3846/btp.2018.14

Idemudia U (2014) Corporate social responsibility and development in Africa: issues and possibilities. Geography Compass 8 (7): 421-435. https://doi.org/10.1111/gec3.12143

Isaksson L (2012) Corporate social responsibility: a study of strategic management and performance in Swedish firms (doctoral dissertation) http://epublications.bond.edu.au/theses/68/

Jegede AE, Adejuwon GA, Olowookere EI, Elegbeley AO (2016) Ecological approach to Nigerian Youth Cyber Fraud participation. The Social Sciences 11 (22): 5284-5293.

Karadeniz M (2009) The importance of creating a successful corporate identity and corporate image for enterprises in marketing management. Journal of Naval Science and Engineering 5 (3): 1-15.

Kurucz EC, Colbert BA, Wheeler D (2008) The business case for corporate social responsibility. In: Crane A, McWilliams A, 
Matten D, Moon J, Siegel D (Eds). The Oxford Handbook of Corporate Social Responsibility. Oxford: Oxford University Press, 83-112.

Motilewa BD, Worlu REK (2015) Corporate social responsibility as a tool for gaining competitive advantage. International Journal of Multidisciplinary Research and Review 1 (1): 16-24.

Mullerat R, Brennan D (2005) Corporate social responsibility: The corporate governance of the $21^{\text {st }}$ century. Kluwer Law International.

Muthuri JN, Gilbert V (2011) An institutional analysis of corporate social responsibility in Kenya. Journal of Business Ethics 98 (3): 467-483. https://doi.org/10.1007/s10551-010-0588-9

Ndu AEO, Agbonifoh BA (2014) Corporate social responsibility in Nigeria: a study of the petroleum industry and the Niger Delta. International Review of Social Sciences and Humanities 6 (2): 214-238.

OECD (2003) Annual Report 2003 https://www.oecd.org/ about/2506789.pdf

Okike ENM (2007) Corporate governance in Nigeria: the status quo. Corporate Governance: An International Review 15 (2): 173-193. https://doi.org/10.1111/j.1467-8683.2007.00553.x

Onakoya AB, Onakoya AO, Jimi-Salami OA, Odedairo BO (2013) Energy consumption and Nigerian economic growth: an empirical analysis. European Scientific Journal 9 (4): 25-40.

Pallant J (2005) SPSS Survival guide: a step by step guide to data analysis using SPSS for Windows (3rd Ed) Open University Press, New York.

Pina JM, Martinez E, De Chernatony L, Drury S (2006) The effect of service brand extensions on corporate image. An empirical model. European Journal of Marketing (1/2): 174-197. https:// doi.org/10.1108/03090560610637374
Rangan K, Chase LA, Karim S (2012) Why every company needs a CSR strategy and how to build it Working paper. Harvard Business School www.hbs.edu/faculty/Publication\%20 Files/12-088.pd

Saunders M, Lewis P, Thornhill A (2009) Research methods for business students (5th Ed). Pearson Education Ltd.

Subai P (2009) Whistle blower protection and environmental corporate responsibility. In: Emiri F, Deinduomo G (Ed) Law and petroleum industry in Nigeria: Current challenges. Lagos: Malthouse Press Limited, 327-338.

Tudor TL, Barr SW, Gilg AW (2008) A novel conceptual approach for examining environmental behavior in large organisations: a case study of the Cornwall National Health Service (NHS) in the United Kingdom. Environment and Behavior 40: 426450. https://doi.org/10.1177/0013916507300664

Umukoro BE (2009) Gas flaring, environmental corporate responsibility and the right to a healthy environment: the case of the Niger Delta. In: Emiri F, Deinduomo G (Ed) Law and Petroleum Industry in Nigeria: Current challenges. Lagos: Malthouse Press Limited, 49-64.

Visser W, Matten D, Pohl M, Tolhurst N (2010) The a to z of corporate social responsibility $\left(2^{\text {nd }} \mathrm{Ed}\right)$. West Sussex: Wiley.

Woolfson C, Beck M (2005) Corporate social responsibility failures in the oil industry. New York: Baywood.

Yeo RK, Youssef MA (2010) Communicating corporate image into existence: the case of the Saudi banking industry. Corporate Communications International Journal 15 (3): 263-280. https://doi.org/10.1108/13563281011068122

Żaba-Nieroda R (2011) Developing corporate image. The Małopolska School of Economics in Tarnów Research Papers Collection 1: 295-307. 